\title{
Review \\ Detergent Plants of Northern Thailand: Potential Sources of Natural Saponins
}

\author{
Jiratchaya Wisetkomolmat ${ }^{1,2}$, Pongsakorn Suppakittpaisarn ${ }^{3}$ and Sarana Rose Sommano ${ }^{2, *}$ (i) \\ 1 Interdisciplinary Program in Biotechnology, Graduate School, Chiang Mai University, \\ Chiang Mai 50200, Thailand; Jiratchaya_wis@cmu.ac.th \\ 2 Plant Bioactive Compound Laboratory (BAC Lab), Department of Plant and Soil Sciences, \\ Faculty of Agriculture, Chiang Mai University, Chiang Mai 50200, Thailand \\ 3 Department of Plant and Soil Sciences, Faculty of Agriculture, Chiang Mai University, \\ Chiang Mai 50200, Thailand; pongsakorn.sup@cmu.ac.th \\ * Correspondence: sarana.s@cmu.ac.th; Tel.: +66-53944040
}

Received: 9 November 2018; Accepted: 27 December 2018; Published: 3 January 2019

\begin{abstract}
The natural forests of Northern Thailand are the mother source of many utilisable natural products because of their diverse flora and fauna. Northern Thai people have learned to utilise plants, in particular those of plants with cleansing properties, since the beginning of time. Several local species of detergent plants in Thailand are traditionally used by the locals and indigenous people. However, these plants may become extinct because their habitats have been replaced by industrial agriculture, and their uses have been replaced by chemically synthesised detergents. Researchers need to study and communicate the biology, phytochemistry, and the importance of these plants to conserve natural biodiversity of Northern Thailand. Of many utilisable detergent phytochemicals, natural saponins are known as bio-based surfactant and foaming agents. Their physiochemical and biological properties feature structural diversity, which leads to many industrial applications. In this review, we explained the term "detergent" from the physiological mechanism perspective and the detergent effects of saponins. We also compiled a list of Thai local plants with cleansing properties focusing on the saponin-containing plants. Future studies should investigate information relative to plant environment, ethnobotanical data, and the bioactive compound content of these plants. The knowledge acquired from this study will promote the maintenance of the local biodiversity and the conservation of the detergent plant species found in Thailand.
\end{abstract}

Keywords: saponin-containing plants; cleansing plants; bio-based surfactant

\section{Introduction}

Plants in the natural forests of South-East Asia are known for the importance sources of natural products. These medical and every-day utilisations derive from the related indigenous knowledge that has been widely observed across generations [1]. These products have provided remedies for the healthcare industry, especially in the past decade [2,3].

The natural forests of Northern Thailand cover the highest percentage of the remaining forests and protected areas of the entire country. They consist of various kinds of tropical forest types, such as evergreen, dry dipterocarp, mixed deciduous, and mangrove forests [3,4]. Due to such diversity of forest types, Thai people and the ethnic minorities have utilised an enormous variety of plants in their lifestyle, i.e., as sources of agricultural products, traditional medicines, clothing, housing, and tools. These Thai forests create a set of unique ethnobotanical knowledge [3].

Since the beginning of this century, there have been an increasing interest in the research of medicinal plants and their traditional uses in different parts of the world. Parts of the interest include the 
chemical compounds that make these plants useful. Some compounds are gaining scientific attention, including saponins. Saponins are among the most well-known bio-based surfactants; they function like natural soap. Recently, saponin-containing plants have increasingly gained interest due to their excellent functional properties and health benefits. Furthermore, using saponin as a cleaning agent is environmentally safe, biodegradable, renewable, as well as ecologically adaptable $[5,6]$.

The rich diversity of the Northern Thai flora can be a unique source of many potential natural products [1]. However, there is no reliable documentation regarding local plants used as detergent or for cleansing purposes in the Northern Thailand [4]. Without formal documentation to continue its utilisation, this group of plants may become extinct. The plants' habitats have been replaced by industrial agriculture, and their uses have been replaced by chemically synthesised detergents. Thai people have reaped the benefits of native detergent plants over hundreds of years, however, recent ethnobotanical studies showed that the number and diversity of such plant species have drastically declined over the past decades. The traditional knowledge regarding their utilisation is gradually being lost. For these reasons, detergent plants, whether listed as threatened species or not, and by virtue of their economic and cultural significance, are at risk of extinction and need renewed attention with respect to their conservation [7].

The cleansing properties in plant bioactive compounds, bio-based surfactants, soap and detergent, are explained herein. We highlighted saponins as the natural product for cleansing industry with promising potentials. We also searched and reviewed works concerning local detergent plants in Northern Thailand to provide baseline information about the ways one can sustainably conserve this group of plants.

\section{Cleansing Properties of Natural Products}

Plants have developed many secondary compounds to protect themselves from hostile environments, insects, or pathogens [8-11]. These compounds pose biological activity that humans have learned to utilise to their benefits for centuries [12]. One type of the chemicals secreted are bio-based surfactants, chemicals that have detergent and soap-like properties. This section examines how and why we can effectively use bio-based surfactants as cleaning agents.

\subsection{Surfactant}

A surfactant is a substance which reduces the surface tension of water and the interfacial tension between oil and water $[13,14]$. Structurally, surfactants contain both hydrophobic and hydrophilic groups called amphipathic molecules [14-20]. The hydrocarbon chain interacts weakly with the water molecules in an aqueous environment, whereas the polar or ionic head group interacts strongly with water molecules via dipole or ion-diploe interactions. It is this powerful interaction with the water molecules that makes surfactants soluble in water [15]. Owing to their unique characteristics, surfactants can self-assemble spontaneously in solutions with various morphologies within spherical micellar structures [16] or gather at the interface to reduce the interfacial tension [14,19]. Due to the behaviour of surfactants, they are widely applicable in chemical industries as wetting, flocculating, and foaming agents, adhesives, cleansing agents, and emulsifiers [13-15,20]. Soap is a type of surfactant that is generally used for cleansing purposes. For this reason, many plants used for cleaning are called soapbark, soapwort, soapnut, soaproot, and soapberry [14,21].

\subsection{Bio-Based Surfactants}

Surfactants can be classified based on where they were obtained: natural and synthetic [14]. The surfactants obtained directly from natural sources are considered natural surfactants. The empirical molecule of bio-based surfactants is mainly glycoside $\left(\mathrm{C}_{26} \mathrm{H}_{31} \mathrm{O}_{10}\right)$ [18]. 


\subsection{Soaps and Detergents}

Surfactants can also be classified based on chemical structures: soap and detergent. Soap and detergent are similar in their general structure and properties but different in their chemical compositions and some specific functionality. Soap is one of the surfactants but the term is usually reserved for synthetic ingredients [22-25]. Soap is the major product of chemical reaction between triglyceride and lye solution. The process is called saponification [26]. This process is the key difference between soap and detergent. Soap molecules contain a polar group, which are usually ionized and soluble in water, and a hydrophobic residue sufficiently large for the whole molecule to display simultaneously both hydrophilic and hydrophobic properties. The hydrocarbon part of the soap is usually a normal chain of 12,16 , or 18 carbon atoms; there is also the common oleic acid of 18 carbon atoms, but with a double bond in the middle [27]. Soaps are limited to the sodium, potassium, ammonium, and amine salts of the fatty acid series from lauric (C12) to stearic (C18), or of rosin or naphthenic acids. Both the alkali used and the combined acid affect the properties and uses of the resulting soaps [22]. Natural soaps are not widely used because they caused high irritation and high deposition. [25]. Thus, although most of the commonly used surfactant plants have the word 'soap' in their names, they are in fact detergent plants.

Detergents are amphipathic molecules considered to be surface-active agents that exhibit unique properties in aqueous solutions, in which they spontaneously form spherical micellar structures in addition to lowering the surface tension of their solution [22,23]. The main purpose of the detergents is to remove stains (usually of protein bases), oils, and other pollutants, without doing irreparable damage or redepositing dirt on to the substance [22,24].

The process of washing with soap and detergent includes the removal of the outer layer of grease in which the dirt is embedded. When we immerse a piece of stained cloth in the surfactant solution and scrub, the surfactant molecules aggregate around the oil molecules such that their nonpolar hydrophobic part points towards the oil while the polar part is directed towards the water. This exerts a net force on the grease or oil due to which they are dislodged and can be washed away easily [19].

\subsection{Foam}

Foam is a visible property of a surfactant. That is, foam in aqueous solution is a dispersion of air bubbles in water surface stabilized by the surface-active agents such as surfactants, proteins, polymers, or macromolecule $[15,28]$. For industrial processes, foams can occur during processing of food, pharmaceutical, and personal care products $[28,29]$. The formation of stable foam is associated with a reduction in surface tension at the liquid-air interface [30]. Adding surfactant is a possible way to enhance foam stability, which is preferable for achieving good texture in food such as ice-cream, beer, cream, and coffee [29].

\section{Saponins}

Many plant products are bio-based surfactants. They produce the compounds known as glycosidically-derivative saponins [14], the best-known plant-based surfactants [13]. Plant-derived saponins have gained increasing attention due to their excellent functional properties, health benefits, and being environmentally safe. They are less toxic, more biodegradable, and more renewable as well as ecologically adaptable than the other type of surfactants $[5,18,19]$. Their physiochemical and biological properties feature structural diversity, which have led to a number of traditional uses, including natural detergents [31] and industrial applications [16].

\subsection{Chemical Structure and Type of Saponins}

Saponins are plant glycosides [32] and non-volatile compounds [33,34], which are widely distributed in many plants species $[5,9,31,35]$. Structurally, saponins are amphiphatic complex of glycosides, steroids and triterpenoids $[9,31,34,35]$. This aglycone is designated to genin or sapogenin which are covalently bound to one or more sugar moieties, polar molecules [32,36-40]. Due to these combinations of a 
hydrophobic aglycone backbone and hydrophilic sugar molecules, saponins are strong surface-active compounds [5,19]. They confer detergent, wetting, foaming, and emulsifying properties [31,37]. According to their surfactant properties, when saponin-containing plants are agitated in water, saponin molecules form soap-like foam, therefore, the Latin term "sapo" is given $[9,31,32,34]$.

These natural compounds offer a diverse range of properties such as pharmacological, haemolytic, antibiotic, insecticidal, and molluscicidal activities [31,34,35]. In plants, saponins are involved in the defence mechanism $[32,38]$ due to their protective molecules called "phytoanticipins" or "phytoprotactants" [36] that perform biological properties against the pathogen and herbivore attacks [35,38] and induce the plant's responses to abiotic stresses [31].

\subsection{Documented Plant Sources of Saponin}

Humans have realised the benefit of saponin-containing plants as medicine and natural detergent [21,31,32]. Saponins have been studied for their wide range of functions [9] including the beneficial physicochemical (e.g., surfactant) and biological (e.g., biocidal and antimicrobial) properties. These properties make saponins of steroidal and triterpenoid types the promising compounds for industrial applications $[31,37,38,41,42]$. Saponins occur in various plant organs such as root, leaf, fruit, bark, and flower $[5,14,38]$. In this section, we discuss previously documented saponin-containing plants across the world.

3.2.1. Soapbark (Quillaja saponaria) or Soap tree is commonly called Quillay or Quillaja tree in South America [6]. The bark extract contains saponins that can form surfactant micelles in water [43]. The foaming properties of the bark were first recognised by the indigenous people of Chile who used aqueous bark extracts as a detergent for washing their hair and clothes $[6,44,45]$. This plant is well known to contain triterpene saponins, (up to $5 \%$ triterpenoid saponins in bark) [6,46]. It is widely used in many industries, including in the personal care products, vaccine adjuvants, [44] and a surfactant in the production of photosensitised film. It is also used as a foaming agent in beverages, shampoos, and natural emulsifier in foods [6].

3.2.2. Soapwort (Saponaria officinalis) is native to Europe and Western to Central Asia and cultivated in many countries throughout the world. Soapwort contains large amounts of saponins which froth when extracted using water $[47,48]$. S. officinalis has been also well known for the detergent property and used to make soap since ancient times [32,47,49]. In folk medicine, it is also used for skin complaints and rheumatic disorders [47].

3.2.3. Soapnut (Sapindus mukorossi), known as Reetha, is generally distributed in tropical and sub-tropical regions of Asia [20,50,51]. The fruits of soapnut are a major source of saponins that have been traditional used as detergent and natural shampoo due to their foaming capability in water $[5,20,52,53]$. Previous phytochemical studies have identified several different types of saponins, such as sesquiterpene oligoglycoside, hederagenin saponins, dammarane-type triterpenoids. Triterpenoid saponins were distributed in the gall, fruit, pericarp, stem, or root [50]. The pericarp of soapnut fruit contained high content of triterpenoid saponins which shown strong surface activity [52]. There are no toxic effects on human skin and eyes for using saponins from soapnut as a washing soap [13]. In the commercial industry, the fruit pericarp extract is an ingredient of a foam stabilising and emulsifying agent in cleansers, shampoos, and cosmetics [50,52].

3.2.4. Soapberry (Sapindus saponaria) is a native plant of Brazil [54], a medium size tree distributed all over the tropics and produce a large amount of small fruits yearly [54-56]. In America, Brazil and India, the fruits are traditionally used to manufacture soap $[57,58]$ and as a clothing detergent $[53,54]$. Soapberry contains saponins in various parts [57]. The fruit pericarp contained monodesmosidic triterpene [55] and bisdesmosidic sesquiterpene saponins, which formed foam when shaken in water [56]. The tree is used as a soap substitute by people in the tropics, for cleaning procedures and for treatment of skin lesions caused by fungi $[55,56]$. 


\section{Detergent Plants in Northern Thailand}

\subsection{Ethnobotanical Studies of Thai Detergent Plants}

Several works have reported the ethnobotanical uses of Thai local/indigenous plants, particularly from the northern region [59-61]. However, little has been established regarding utilisation of our detergent plants or plants used in cleansing purposes. In this study, we reviewed the literature on ethnobotany from different rural communities of Northern Thailand. After examining bibliographical sources including published journal articles, thesis, other books, and personal communications with an ethnobotanist, we found that there were 18 plant families used for cleansing purposes (Table 1).

Table 1. Local/indigenous plants used for cleansing purposes in Northern Thailand.

\begin{tabular}{|c|c|c|c|c|}
\hline Family & Identified Species & Part Used & Utilisations & $\overline{\text { References }}$ \\
\hline Arecaceae & Acorus gramineus Aiton & Leaf & Mashed and used as shampoo & [62] \\
\hline Burseraceae & Garuga pinnata Roxb. & Leaf & Mashed and used as shampoo & {$[62]$} \\
\hline Clusiaceae & Garcinia sp. & Fruit & Mashed and used as shampoo & [62] \\
\hline \multirow[t]{2}{*}{ Cucurbitaceae } & Luffa cylindrica Roem. & Fruit & $\begin{array}{l}\text { Fibre of dried fruit is used as } \\
\text { similar to cleansing sponge }\end{array}$ & {$[63]$} \\
\hline & Trichosanthes cucumerina Linn. & Fruit & $\begin{array}{l}\text { Fibre of dried fruit is used as } \\
\text { similar to cleansing sponge }\end{array}$ & $\begin{array}{l}\text { Inta, per. } \\
\text { comm. }\end{array}$ \\
\hline Dilleniaceae & Dillenia parviflora Griff. & Fruit & $\begin{array}{l}\text { Mashed as used as shampoo } \\
\text { hair dying agent (black) }\end{array}$ & [62] \\
\hline \multirow{3}{*}{ Euphorbiaceae } & Antidesma acidum Retz. & Leaf & $\begin{array}{l}\text { Mashed as used as shampoo } \\
\text { hair dying agent (black) }\end{array}$ & $\begin{array}{l}\text { Inta, per. } \\
\text { comm. }\end{array}$ \\
\hline & Homonoia riparia Lour. & Leaf & Detergent for hand wash & {$[64]$} \\
\hline & Flueggea virosa (Willd.) Voigt & Stem & $\begin{array}{l}\text { Mashed, soaked in water and } \\
\text { used as detergent or shampoo }\end{array}$ & {$[62]$} \\
\hline \multirow[t]{2}{*}{ Fabaceae } & Acacia concinna (Willd.) D.C. & Fruit & $\begin{array}{l}\text { Shampoo } \\
\text { Used for spiritual cleansing } \\
\text { during Thai new year }\end{array}$ & [65] \\
\hline & Clitoria ternatea $\mathrm{L}$. & Leaf & Mixed with shampoo & [62] \\
\hline Hypoxidaceae & $\begin{array}{l}\text { Curculigo latifolia Dryand. ex. } \\
\text { W.T. Aiton }\end{array}$ & Rhizome & Mashed and used as shampoo & [62] \\
\hline Lauraceae & Litsea glutinosa (Lour.) C.B. Rob. & Leaf & Mashed and used as shampoo & {$[65,66]$} \\
\hline Oxalidaceae & Oxalis corniculata L. & $\begin{array}{l}\text { Stem } \\
\text { Leaf }\end{array}$ & $\begin{array}{l}\text { Used to polish silver and gold } \\
\text { wares }\end{array}$ & {$[64,65]$} \\
\hline Pedeliaceae & Sesamun orientale L. & Leaf & Mashed and used as shampoo & [62] \\
\hline Poaceae & Oryza sativa $\mathrm{L}$. & Peel & $\begin{array}{l}\text { Fibre of dried fruit is used as } \\
\text { similar to cleansing sponge }\end{array}$ & {$[67]$} \\
\hline Rutaceae & Citrus hystrix D.C. & Fruit & Used as shampoo & {$[66]$} \\
\hline Salicaceae & Salix tetrasperma Roxb. & Pericarp & Used as detergent & {$[62]$} \\
\hline \multirow{3}{*}{ Sapindaceae } & Aesculus assamica Griff. & Leaf & Used as shampoo & $\begin{array}{l}\text { Inta, per. } \\
\text { comm. }\end{array}$ \\
\hline & $\begin{array}{l}\text { Lepisanthes rubiginosa (Roxb.) } \\
\text { Leenh. }\end{array}$ & Fruit & Used as shampoo & $\begin{array}{l}\text { Inta, per. } \\
\text { comm. }\end{array}$ \\
\hline & Sapindus rarak D.C. & Fruit & $\begin{array}{l}\text { Mashed, soaked in water and } \\
\text { used as detergent or shampoo }\end{array}$ & {$[62,66]$} \\
\hline Solanaceae & Solanum erianthum D.Don & Leaf & $\begin{array}{l}\text { Fresh leaf is used to polish kitchen } \\
\text { wares }\end{array}$ & {$[63,66]$} \\
\hline Teliaceae & Microcos tomentosa Sm. & Leaf & Shampoo & $\begin{array}{l}\text { Inta, per. } \\
\text { comm. }\end{array}$ \\
\hline \multirow[t]{2}{*}{ Vitaceae } & Cissus modeccoides Var. Karri. & Leaf, Stem & $\begin{array}{l}\text { Used to polish kitchen wares } \\
\text { (boiled in water) }\end{array}$ & $\begin{array}{l}\text { Inta, per. } \\
\text { comm. }\end{array}$ \\
\hline & Cissus repen Lamk. & Stem & $\begin{array}{l}\text { Used to polish silver wares } \\
\text { (boiled in water) }\end{array}$ & [64] \\
\hline
\end{tabular}




\subsection{Frequently Mentioned Detergent Plants in Northern Thailand}

During our review, we found a few plant species that were mentioned consistently. These plants include Litsea glutinosa, Sapindus rarak, and Acacia concinna.

\subsubsection{Litsea glutinosa}

Botanical description and distribution: Litsea glutinosa (Lour.) C.B. Robinson belongs to the Lauraceae family. It is distributed throughout South Asia and Southeast Asia, including India, Bangladesh, the Philippines, and Thailand [68-71]. It is a medium-sized plant, approximately $20 \mathrm{~m}$ tall $[68-70,72,73]$. The branch shape is slim, stiff, and tomentose towards the apex. The bark is thin, ranging from grey to brown; the live bark is $3 \mathrm{~mm}$ thick, pale brown, and very slimy when wet. The leaf size varies between $7-15 \mathrm{~cm} \times 3-7 \mathrm{~cm}$. They are spirally arranged. The shape of the leaf is usually oblong-oval or elliptic lateral. Each petiole is $1.5-3 \mathrm{~cm}$ long. The flowers are arranged in umbels approximately $4-5 \mathrm{~mm}$ in diameter and the peduncles are up to $5 \mathrm{~mm}$ long. The fruit size is around $6 \mathrm{~mm}$ in diameter with purplish black colour [72].

Phytochemistry: The common constituents found in L. glutinosa include tannin, alkaloids, sterols and some flavonoids. Its fruits contain essential oils with more than 30 compounds, predominantly (E)- $\beta$-ocimene, the minor constituents in oils were caryophyllene oxide, $\beta$-caryophyllene, and (Z)- $\beta$-ocimene [68]. Its bark contains laurotetanine, actinodaphine, boldine, norboldine, sebiferine, and litseferine. The leaves contain compounds such as flavonoid naringenin, naringin, kaempferol-3, and 7-glucosides and quercetin. The seeds contain fatty acids and 20\% tannins [72].

Pharmacology and utilisations: L. glutinosa has been used as traditional medicines due to various biological activities such as antispasmodic, antibacterial, and cardiovascular activities [68,71]. The bark and leaves (Figure 1) were used as a demulcent and a mild astringent for diarrhoea and dysentery due to balsamic and mucilaginous nature, while the paste from its roots is used as poultice for sprains and bruises [69,70,72]. The leaf extract of L. glutinosa showed significant antinociceptive property against chemical and thermal stimuli [70]. Aromatic oil from seeds is used to make candles and soap [70,72]. Since the extraction is difficult and the yield is very low, the oil is costly and less commonly used [68].

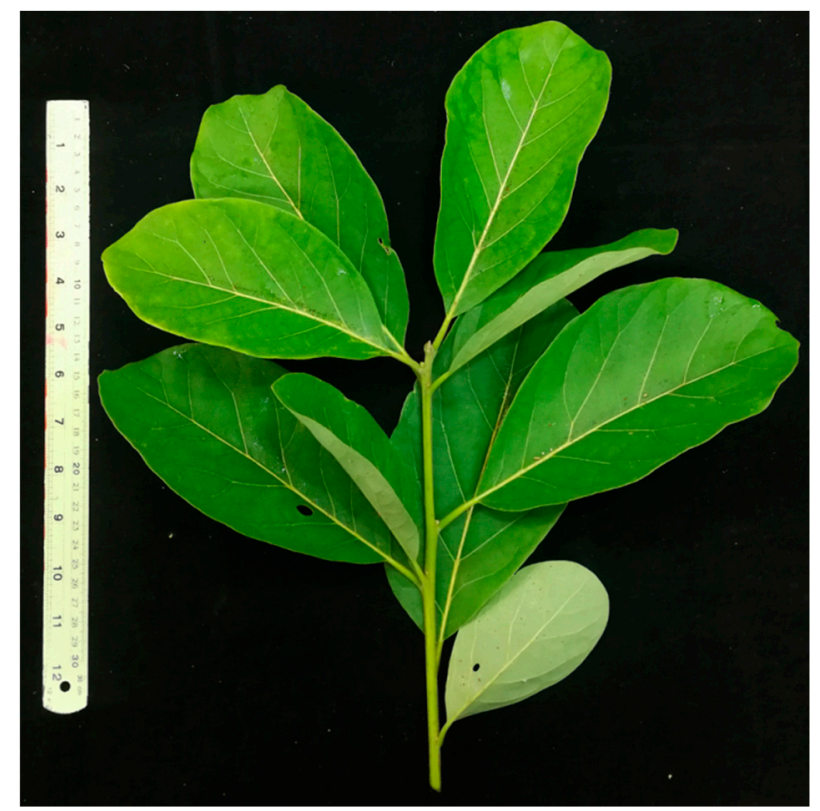

Figure 1. Leaves of Lisea glutinosa. 


\subsubsection{Sapindus rarak}

Botanical description and distribution: Sapindus rarak belongs to the family Sapindaceae and is widely distributed across Africa, South Asia, and South East Asia such as Indonesia, Bhutan, China, and Thailand [8,74-79]. This plant is a tall tree, ranging from 10 to $42 \mathrm{~m}$ in height, with diameter at breast height of $1 \mathrm{~m}$. The inflorescence is panicle, terminal, and conical with the length of $19-40 \mathrm{~cm}$. [77]. The fruits are circular in shape with $2-2.5 \mathrm{~cm}$. diameters, consisting of a hard seed coat. The unripe fruits are soft and brown and become dark brown or blackish brown when they are ripe or dried. The pericarp is thin and has a fragrant aroma $[8,77]$.

Phytochemistry: The methanolic extract of the pericarps contain various saponins, such as acylated oleanane-type triterpene saponins, rarasaponins, and hederagenin [8,75,77].

Pharmacology and utilisations: In Thailand, the pericarps of S. rarak (Figure 2) have been used in traditional medicine and as a source of natural surfactant, displaying a foaming property. The methanol extract from this plant parts shows an inhibitory effect on pancreatic lipase activity and on skin irritants $[8,75,76]$. The fruits pericarp of $S$. rarak are commonly used for cleaning and washing clothes [74] and, traditionally, as a natural detergent and medicine. In addition, local people in Bhutan have been used them as shampoo ingredient for eliminating lice [78]. The natural detergent from the pericarp is environmentally friendly compared to chemical soap. Saponins from S. rarak have a moluscisidal activity which can be used as biopesticide [77] and a potential for a defaunating agent [8].

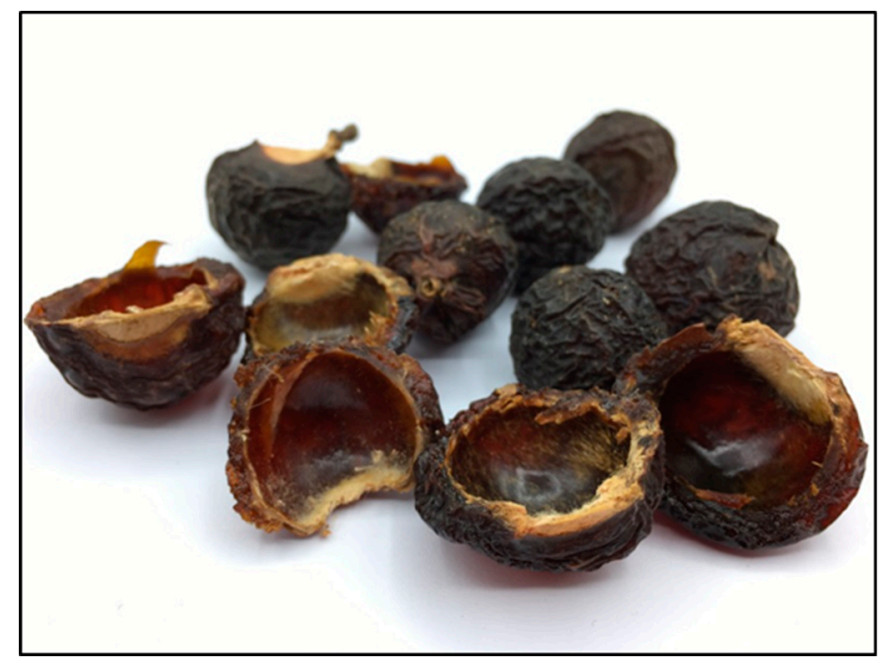

Figure 2. Fruits of Sapindus rarak.

\subsubsection{Acacia concinna}

Botanical description and distribution: Acacia concinna, commonly known as Skikakai in Hindi or Sompoi in Thai, is a climbing shrub. It belongs to the Fabaceae family. This medicinal plant grows widely in tropical forests in Southern Asia, such as India, Myanmar, and Thailand [80-85]. The plant is deciduous and perennial. The leaves begin falling with the onset flowering season. The flowers are small, globose heads, bisexual, and actinomorphic. In each flower, the stamens are fertile, and the ovary is monocarpellary with a single locule [86].

Phytochemistry: The pod of A. concinna contain several saponins, highly polar compounds, such as prosapogenol, and monoterpene glycoside in various parts of the plant $[81,82,87,88]$. The structures of several triterpene genins and prosapogenins were found [81]. The bark and pod also contain high levels of saponins which are foaming agents, a natural surfactant $[82,83]$.

Pharmacology and utilisations: In the northern part of Thailand, the locals use the pods of Sompoi (Figure 3) as one ingredient of Thai traditional holy water to sacrifice for senior people [85]. In India, the fruits are used as a traditional shampoo, and the saponins from the pods are also traditionally used as a natural detergent [83]. Furthermore, the saponins in the pods are shown to have antidermatophyte 
and antimicrobial properties. The pods are used as antidandruff shampoo, can promote hair growth. For medicinal purposes, it has also used as an expectorant and purgative $[80,81,85,88]$. The saponins from the bark have spermicidal activity against human semen [82]. Chavan and Bandgar [83] reported that the aqueous extract from $A$. concinna pods is efficient to the economy and environment as a catalyst for the synthesis of 3-carboxycoumarins and cinnamic acids. Moreover, the allelopathic property from the pod extract can inhibited growth of some plants species. Thus, the plant extract could be utilised as a weed management option in sustainable agriculture [84].

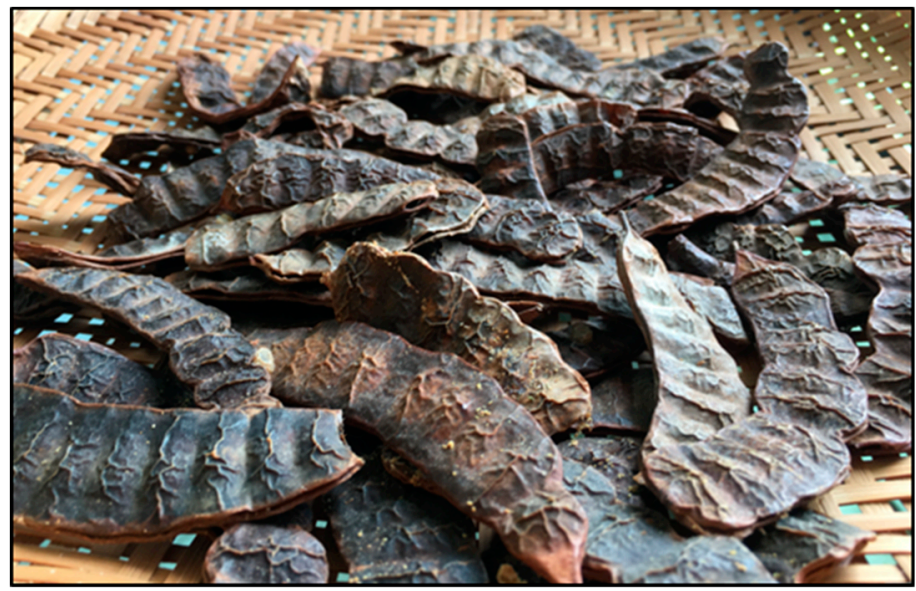

Figure 3. Pods of Acacia concinna.

\section{Discussion}

In the context of chemical structure, we have given the definition of detergent plants based upon their emulsifying property from the major compounds found in these plants, which are saponins. Detergent differs from soap because of the chemical reaction between triglyceride and lye solution, the process called saponification [26]. Both detergent and soap can produce foam, which in aqueous solution, is a dispersion of air bubbles in water surface stabilised by surface-active agents such as surfactants, proteins, polymers, or macromolecules. Owing to their characteristics, they are widely applicable in many industries as wetting, foaming, and cleaning agent. Other uses include bio-insecticides, natural food additives, and medicine. Saponins can be found in detergent plant group such as soapbark, soapwort, soapnut, and soapberry. In Thailand, we found that detergent plants have been used for cleansing purposes, such as scrubs, perfume, and other cleaning products due to their detergent property. They are also used for spiritual cleansing. The detergent plants found in indigenous Thai records include Litsea glutinosa, Sapindus raruk, and Acacia concinna. These plants have potential to be natural saponin sources.

The knowledge acquired form this review will increase attention on the utilisation of local medicinal plants; such information can be used to research and development of the natural products for the commercial industries. This resonates with the fact that the global market for herbal medicine has increased due to the contribution of the significant health and economic values of herbal products [26].

However, developing natural substances into commercial products may lead to an overconsumption of natural resources. This is concerning because we also found that the knowledge of how to use these plants is lacking. We should consider a sound conservation plan along with the study of product development. Thus, it is necessary to consider the drivers that will lead to conversation and utilise these plants in sustainable ways. In this discussion, we gathered the information which will help us understand the importance of biological diversity. The evaluation of a sustainable conservation method requires the understanding and monitoring of local ecosystem functions before, during, and after the use of its renewable products [89]. Therefore, the knowledge supporting the conservation of medicinal and utilisable plants not only has a positive impact on the target plants, but also on their natural habitats and the ecosystem hosting such protected plants [90]. 


\subsection{Driving Factors for Conservation}

Based on currently accessible literature reviews, the most influential factors that drive the needs for the conservation of endangered plant species can be grouped into three main categories: (1) social drivers, (2) environmental drivers, and (3) economic drivers.

\subsubsection{Social Drivers}

Through continuous contact with their natural environment, humans have developed a broad knowledge of locally harvested plants, leading to a variety of utilisations over time [91]. Consequently, many plant species have been, and still are, of central importance to human health and welfare in every part of the world [61,92]. Ethnobotany, the study of the interactions and relationships between plants and people over time and space, plays a significant role in community development and biodiversity conservation, as it can strengthen the links between human beings and their environment. It is, thus, a cornerstone in preserving human-related plant diversity, as well as in understanding and interpreting the acquired knowledge thereof, ultimately enabling societies to conserve them in a sustainable way. By doing so, the knowledge of local plants can also be conserved as part of a living cultural-ecological system, contributing to maintain a sense of pride in local culture and practices and reinforcing the links between communities and their environment, which are, in turn, essential to support ecological conservation [61].

\subsubsection{Environmental Drivers}

The tropical forests of Southeast Asia have been acknowledged as one of the richest regions of biological diversity in the world [93] and the loss of such forests may have drastic long-term effects, including changes in regional climate patterns [94]. Field-collected data provides useful information on floristic composition, plant diversity, and on the relationship of individual plant species with their environment and are essential to the understanding of forest ecological dynamics. The conservation and management of forest resources also requires crucial data on plant species diversity and on forest communities in order to assess the actions necessary for restoring and rehabilitating such forests. In the face of rapid deforestation rates and increasing habitat degradation, there is an urgency to generate information and to assist national and regional actions towards the maintenance of local forest ecosystems [95].

\subsubsection{Economical Drivers}

National resources are the basis for an economy operating in quantitative terms. Therefore, a quantitative description of the resource flows, set targets and how these should be assessed is necessary to promote and enable resource-use in a sustainable way [96]. There is, however, still little understanding of how integrating information on continuous species responses to management efforts into conservation planning could improve the cost-effectiveness of abating threats to species [97]. There are, to date, relatively few articles in the scientific literature that document the establishment, spread, biological characteristics, and guidelines in order to implement an effective management of local detergent plants in Thailand. Thus, to enhance the incomes generated by local detergent plants by using cost-benefit analysis, a better understanding of the marketing needs is required in order to assess the amount of collections, marketing channels and prices at each level for a product derived from a local detergent plant to attain sustainable harvesting [98] and to simultaneously promote the maintenance of local biodiversity in a sustainable and environmentally-friendly manner.

\section{Conclusions}

For the purpose of this review, we aimed to describe the properties, diversity, and conservation of the detergent plant in Northern Thailand. We initially clarified the term "detergent plant" by its chemical properties. Secondly, we investigated the known saponin sources around the world and 
gave examples of saponin plants in Northern Thailand. Finally, we discussed the driving factors for the conservation of this plant group. The knowledge acquired form this review will lead to the conservation of this group of local plants. Understanding the value of local plants will expand to the conservation and maintenance of local biodiversity, which is a part of global ecological system.

Author Contributions: Conceptualization: S.R.S.; writing-original draft preparation: J.W.; writing-review and editing: P.S. and S.R.S.; supervision: P.S. and S.R.S.; project administration: J.W.; funding acquisition: S.R.S.

Funding: This research received grant from the graduate school of Chiang Mai University for Teaching Assistant and Research Assistant grant to J.W. and also the financial support provided by Huai Hong Krai Royal Development Study Centre.

Acknowledgments: We would like to thank Angkhana Inta for ethnobotanical information of Northern Thai detergent plants.

Conflicts of Interest: The authors declare no conflict of interest.

\section{References}

1. Cheikhyoussef, A.; Mapaure, I.; Shapi, M. The use of some indigenous plants for medicinal and other purposes by local communities in Namibia with emphasis on Oshikoto region: A review. Res. J. Med. Plant 2011, 5, 406-419.

2. Van Seters, A.P. Forest based medicines in traditional and cosmopolitan health care. In Medicinal Plants for Forest Conservation and Health Care, Non-Wood Forest Products; Bodeker, G., Bhat, K.K.S., Burley, J., Vantomme, P., Eds.; Food and Agriculture Organization: Rome, Italy, 1997; pp. 5-11.

3. Baimai, V. Biodiversity in Thailand. JR Inst. Thail. 2010, 2, 107-114.

4. Trisurat, Y.; Alkemade, R.; Verburg, P.H. Projecting land-use change and its consequences for biodiversity in Northern Thailand. Environ. Manag. 2010, 45, 626-639. [CrossRef] [PubMed]

5. Samal, K.; Das, C.; Mohanty, K. Eco-friendly biosurfactant saponin for the solubilization of cationic and anionic dyes in aqueous system. Dyes Pigments 2017, 140, 100-108. [CrossRef]

6. Martín, R.S.; Briones, R. Industrial uses and sustainable supply of Quillaja saponaria (Rosaceae) saponins. Econ. Bot. 1999, 53, 302-311. [CrossRef]

7. Ncube, B.; Finnie, J.F.; Van Staden, J. Seasonal variation in antimicrobial and phytochemical properties of frequently used medicinal bulbous plants from South Africa. S. Afr. J. Bot. 2011, 77, 387-396. [CrossRef]

8. Wina, E.; Muetzel, S.; Hoffmann, E.; Makkar, H.P.S.; Becker, K. Saponins containing methanol extract of Sapindus rarak affect microbial fermentation, microbial activity and microbial community structure in vitro. Anim. Feed Sci. Technol. 2005, 121, 159-174. [CrossRef]

9. Faizal, A.; Geelen, D. Saponins and their role in biological processes in plants. Phytochem. Rev. 2013, 12, 877-893. [CrossRef]

10. Xia, P.; Guo, H.; Ru, M.; Yang, D.; Liang, Z.; Yan, X.; Liu, Y. Accumulation of saponins in Panax notoginseng during its growing seasons. Ind. Crops Prod. 2017, 104, 287-292. [CrossRef]

11. Singh, B.; Kaur, A. Control of insect pests in crop plants and stored food grains using plant saponins: A review. LWT_Food Sci. Technol. 2018, 87, 93-101. [CrossRef]

12. Myers, D. Surfactant Science and Technology; John Wiley \& Sons: Hoboken, NJ, USA, 2005.

13. Pradhan, A.; Bhattacharyya, A. Quest for an eco-friendly alternative surfactant: Surface and foam characteristics of natural surfactants. J. Clean. Prod. 2017, 150, 127-134. [CrossRef]

14. Sahu, S.S.; Gandhi, I.S.R.; Khwairakpam, S. State-of-the-Art Review on the Characteristics of Surfactants and Foam from Foam Concrete Perspective. J. Inst. Eng. (India) Ser. A 2018, 99, 391-405. [CrossRef]

15. Tadros, T.F. Applied Surfactants: Principles and Applications; John Wiley \& Sons: Hoboken, NJ, USA, 2006.

16. Bouillon, C. Shampoos. Clin. Dermatol. 1996, 14, 113-121. [CrossRef]

17. Holmberg, K. Natural surfactants. Curr. Opin. Colloid Interface Sci. 2001, 6, 148-159. [CrossRef]

18. Bulbul, B.; Minti, G. Plant based natural surfactants. Asian J. Home Sci. 2013, 8, 759-762.

19. Basu, A.; Basu, S.; Bandyopadhyay, S.; Chowdhury, R. Optimization of evaporative extraction of natural emulsifier cum surfactant from Sapindus mukorossi-Characterization and cost analysis. Ind. Crops Prod. 2015, 77, 920-931. [CrossRef]

20. Muntaha, S.-T.; Khan, M.N. Natural surfactant extracted from Sapindus mukurossi as an eco-friendly alternate to synthetic surfactant-A dye surfactant interaction study. J. Clean. Prod. 2015, 93, 145-150. [CrossRef] 
21. Oleszek, W.; Hamed, A. Saponin-Based Surfactants. In Surfactants from Renewable Resources; John Wiley \& Sons, Ltd.: Hoboken, NJ, USA, 2010; pp. 239-249.

22. Niven, W.W., Jr. Industrial Detergency; Reinhold Publishing Corporation: New York, NY, USA, 1955.

23. Seddon, A.M.; Curnow, P.; Booth, P.J. Membrane proteins, lipids and detergents: Not just a soap opera. Biochimica et Biophysica Acta (BBA)_Biomembranes 2004, 1666, 105-117. [CrossRef]

24. Bhat, R.; Prajna, P.; Menezez, V.P.; Shetty, P. Antimicrobial activities of soap and detergents. Adv. Biores. 2011, 2, 52-62.

25. Gray, J. Hair care and hair care products. Clin. Dermatol. 2001, 19, 227-236. [CrossRef]

26. Atolani, O.; Olabiyi, E.T.; Issa, A.A.; Azeez, H.T.; Onoja, E.G.; Ibrahim, S.O.; Zubair, M.F.; Oguntoye, O.S.; Olatunji, G.A. Green synthesis and characterisation of natural antiseptic soaps from the oils of underutilised tropical seed. Sustain. Chem. Pharm. 2016, 4, 32-39. [CrossRef]

27. Durham, K. Surface Activity and Detergency; Macmillan: London, UK, 1961.

28. Chen, X.W.; Yang, D.X.; Zou, Y.; Yang, X.Q. Stabilization and functionalization of aqueous foams by Quillaja saponin-coated nanodroplets. Food Res. Int. 2017, 99, 679-687. [CrossRef] [PubMed]

29. Dickinson, E. Food emulsions and foams: Stabilization by particles. Curr. Opin. Colloid Interface Sci. 2010, 15, 40-49. [CrossRef]

30. Amankeldi, F.; Ospanova, Z.; Musabekov, K. Composite Foaming Agents on the Basis of High-Molecular Natural Surfactants. Colloids Interfaces 2018, 2, 2. [CrossRef]

31. Kregiel, D.; Berlowska, J.; Witonska, I.; Antolak, H.; Proestos, C.; Babic, M.; Babic, L.; Zhang, B. Saponin-Based, Biological-Active Surfactants from Plants. In Application and Characterization of Surfactants; Najjar, R., Ed.; InTech: Rijeka, Croatia, 2017; 68062p.

32. Osbourn, A. Saponins and plant defence-A soap story. Trends Plant Sci. 1996, 1, 4-9. [CrossRef]

33. Hostettmann, K.; Marston, A. Saponins; Cambridge University Press: Cambridge, UK, 2005.

34. Vincken, J.P.; Heng, L.; de Groot, A.; Gruppen, H. Saponins, classification and occurrence in the plant kingdom. Phytochemistry 2007, 68, 275-297. [CrossRef] [PubMed]

35. Sparg, S.G.; Light, M.E.; van Staden, J. Biological activities and distribution of plant saponins. J. Ethnopharmacol. 2004, 94, 219-243. [CrossRef] [PubMed]

36. Francis, G.; Kerem, Z.; Makkar, H.P.S.; Becker, K. The biological action of saponins in animal systems: A review. Br. J. Nutr. 2007, 88, 587-605. [CrossRef] [PubMed]

37. Güçlü Üstündağ, Ö.; Mazza, G. Saponins: Properties, Applications and Processing. Crit. Rev. Food Sci. Nutr. 2007, 47, 231-258. [CrossRef] [PubMed]

38. Augustin, J.M.; Kuzina, V.; Andersen, S.B.; Bak, S. Molecular activities, biosynthesis and evolution of triterpenoid saponins. Phytochemistry 2011, 72, 435-457. [CrossRef]

39. Singh, B.; Singh, J.P.; Singh, N.; Kaur, A. Saponins in pulses and their health promoting activities: A review. Food Chem. 2017, 233, 540-549. [CrossRef] [PubMed]

40. Tippel, J.; Gies, K.; Harbaum-Piayda, B.; Steffen-Heins, A.; Drusch, S. Composition of Quillaja saponin extract affects lipid oxidation in oil-in-water emulsions. Food Chem. 2017, 221, 386-394. [CrossRef] [PubMed]

41. Heng, W.; Ling, Z.; Na, W.; Youzhi, G.; Zhen, W.; Zhiyong, S.; Deping, X.; Yunfei, X.; Weirong, Y. Analysis of the bioactive components of Sapindus saponins. Ind. Crops Prod. 2014, 61, 422-429. [CrossRef]

42. Ruiz, K.B.; Khakimov, B.; Engelsen, S.B.; Bak, S.; Biondi, S.; Jacobsen, S.-E. Quinoa seed coats as an expanding and sustainable source of bioactive compounds: An investigation of genotypic diversity in saponin profiles. Ind. Crops Prod. 2017, 104, 156-163. [CrossRef]

43. Yang, Y.; Leser, M.E.; Sher, A.A.; McClements, D.J. Formation and stability of emulsions using a natural small molecule surfactant: Quillaja saponin (Q-Naturale ${ }^{\circledR}$ ). Food Hydrocoll. 2013, 30, 589-596. [CrossRef]

44. Arrau, S.; Delporte, C.; Cartagena, C.; Rodríguez-Díaz, M.; González, P.; Silva, X.; Cassels, B.K.; Miranda, H.F. Antinociceptive activity of Quillaja saponaria Mol. saponin extract, quillaic acid and derivatives in mice. J. Ethnopharmacol. 2011, 133, 164-167. [CrossRef] [PubMed]

45. Sarkhel, S. Evaluation of the anti-inflammatory activities of Quillaja saponaria Mol. saponin extract in mice. Toxicol. Rep. 2016, 3, 1-3. [CrossRef] [PubMed]

46. Böttcher, S.; Drusch, S. Saponins-Self-assembly and behavior at aqueous interfaces. Adv. Colloid Interface Sci. 2017, 243, 105-113. [CrossRef]

47. Jia, Z.; Koike, K.; Nikaido, T.; Saponarioside, C. The first $\alpha$-D-Galactose containing triterpenoid saponin, and five related compounds from Saponaria officinalis. J. Nat. Prod. 1999, 62, 449-453. [CrossRef] 
48. Sengul, M.; Ercisli, S.; Yildiz, H.; Gungor, N.; Kavaz, A.; Çetin, B. Antioxidant, Antimicrobial Activity and Total Phenolic Content within the Aerial Parts of Artemisia absinthum, Artemisia santonicum and Saponaria officinalis. Iran. J. Pharm. Res. 2011, 10, 49-56.

49. Koike, K.; Jia, Z.; Nikaido, T. New triterpenoid saponins and sapogenins from Saponaria officinalis. J. Nat. Prod. 1999, 62, 1655-1659. [CrossRef] [PubMed]

50. Chen, C.-Y.; Kuo, P.-L.; Chen, Y.-H.; Huang, J.-C.; Ho, M.-L.; Lin, R.-J.; Chang, J.-S.; Wang, H.-M. Tyrosinase inhibition, free radical scavenging, antimicroorganism and anticancer proliferation activities of Sapindus mukorossi extracts. J. Taiwan Inst. Chem. Eng. 2010, 41, 129-135. [CrossRef]

51. Samal, K.; Das, C.; Mohanty, K. Application of saponin biosurfactant and its recovery in the MEUF process for removal of methyl violet from wastewater. J. Environ. Manag. 2017, 203, 8-16. [CrossRef] [PubMed]

52. Li, R.; Wu, Z.L.; Wang, Y.J.; Li, L.L. Separation of total saponins from the pericarp of Sapindus mukorossi Gaerten. by foam fractionation. Ind. Crops Prod. 2013, 51, 163-170. [CrossRef]

53. Sati, P.; Pandey, A.; Rawat, S.; Rani, A. Phytochemicals and antioxidants in leaf extracts of Ginkgo biloba with reference to location, seasonal variation and solvent system. J. Pharm. Res. 2013, 7, 804-809. [CrossRef]

54. Damke, E.; Tsuzuki, J.K.; Chassot, F.; Cortez, D.A.; Ferreira, I.C.; Mesquita, C.S.; da-Silva, V.R.; Svidzinski, T.I.; Consolaro, M.E. Spermicidal and anti-Trichomonas vaginalis activity of Brazilian Sapindus saponaria. BMC Complement. Altern. Med. 2013, 13, 196. [CrossRef] [PubMed]

55. Murgu, M.; Rodrigues-Filho, E. Dereplication of glycosides from Sapindus saponaria using liquid chromatography-mass spectrometry. J. Braz. Chem. Soc. 2006, 17, 1281-1290. [CrossRef]

56. Amaral, L.S.; Murgu, M.; Rodrigues-Fo, E.; de Souza, A.Q.L.; de Moura Sarquis, M.I. A saponin tolerant and glycoside producer xylariaceous fungus isolated from fruits of Sapindus saponaria. World J. Microbiol. Biotechnol. 2008, 24, 1341-1348. [CrossRef]

57. Meyer Albiero, A.L.; Aboin Sertié, J.A.; Bacchi, E.M. Antiulcer activity of Sapindus saponaria L. in the rat. J. Ethnopharmacol. 2002, 82, 41-44. [CrossRef]

58. Tsuzuki, J.K.; Svidzinski, T.I.; Shinobu, C.S.; Silva, L.F.; Rodrigues-Filho, E.; Cortez, D.A.; Ferreira, I.C. Antifungal activity of the extracts and saponins from Sapindus saponaria L. Anais da Academia Brasileira de Ciencias 2007, 79, 577-583. [CrossRef]

59. Panyadee, P.; Balslev, H.; Wangpakapattanawong, P.; Inta, A. Woody plant diversity in urban homegardens in Northern Thailand. Econ. Bot. 2016, 70, 285-302. [CrossRef]

60. Srithi, K.; Balslev, H.; Wangpakapattanawong, P.; Srisanga, P.; Trisonthi, C. Medicinal plant knowledge and its erosion among the Mien (Yao) in Northern Thailand. J. Ethnopharmacol. 2009, 123, 335-342. [CrossRef] [PubMed]

61. Srithi, K.; Trisonthi, C.; Wangpakapattanawong, P.; Balslev, H. Medicinal plants used in Hmong women's healthcare in northern Thailand. J. Ethnopharmacol. 2012, 139, 119-135. [CrossRef] [PubMed]

62. Songsangchun, A. Plants Usages of Khon Muang and Lawa in Phu Fah Subdistrict, Bo Klua District, Nan Province. Master's Thesis, Chiang Mai University, Chiang Mai, Thailand, July 2015.

63. Moonjai, J.; Inta, A. Ethnobotanical study of the Lawa lived in La-Oob village, Mae La Noi district, Mae Hong Son province. Thai J. of Bot. 2016, 8, 181-199.

64. Tovaranonte, J. Ethnobotanical Study of the Tai Lue, Hmong and Yao in Some Areas of Nan Province. Master's Thesis, Chiang Mai University, Chiang Mai, Thailand, July 1998.

65. Panyadee, P. Plant Diversity in Homegardens of Tai Yai Communities in Pang Mapha District, Mae Hong Son Province. Master's Thesis, Chiang Mai University, Chiang Mai, Thailand, May 2012.

66. Muangyen, N. Ethnobotany of Tai Lue and Tai Yuan in Samoeng District, Chiang Mai Province. Master's Thesis, Chiang Mai University, Chiang Mai, Thailand, March 2013.

67. Kamwong, K. Ethnobotany of Karens at Ban Mai Sawan and Ban Huay Pu Ling, Ban Luang Sub-District, Chom Thong District, Chiang Mai Province. Master's Thesis, Chiang Mai University, Chiang Mai, Thailand, February 2009.

68. Chowdhury, J.U.; Bhuiyan, M.N.I.; Nandi, N.C. Aromatic plants of Bangladesh: Essential oils of leaves and fruits of Litsea glutinosa (Lour.) CB Robinson. Bangladesh J. Bot. 2008, 37, 81-83. [CrossRef]

69. Das, D.; Maiti, S.; Maiti, T.K.; Islam, S.S. A new arabinoxylan from green leaves of Litsea glutinosa (Lauraeae): Structural and biological studies. Carbohydr. Polym. 2013, 92, 1243-1248. [CrossRef] [PubMed]

70. Pradeepa, K.; Krishna, V.; Santosh, K.; Girish, K.K. Antinociceptive property of leaves extract of Litsea glutinosa. Asian J. Pharm. Clin. Res. 2013, 6, 182-184. 
71. Haque, T.; Uddin, M.Z.; Saha, M.L.; Mazid, M.A.; Hassan, M.A. Propagation, antibacterial activity and phytochemical profiles of Litsea glutinosa (Lour.) CB Robinson. Dhaka Univ. J. Biol. Sci. 2014, 23, 165-171. [CrossRef]

72. Devi, P.; Meera, R. Study of antioxdant, antiinflammatory and woundhealing activity of extracts of Litsea glutinosa. J. Pharm. Sci. Res. 2010, 2, 155.

73. Wang, Y.S.; Wen, Z.Q.; Li, B.T.; Zhang, H.B.; Yang, J.H. Ethnobotany, phytochemistry, and pharmacology of the genus Litsea: An update. J. Ethnopharmacol. 2016, 181, 66-107. [CrossRef]

74. Nasution, R.E. Perkarangan: Suatu tinjauan peranannya. Bul. Kebun Raya 1979, 4, 33-39.

75. Asao, Y.; Morikawa, T.; Xie, Y.; Okamoto, M.; Hamao, M.; Matsuda, H.; Muraoka, O.; Yuan, D.; Yoshikawa, M. Structures of acetylated oleanane-type triterpene saponins, rarasaponins IV, V, and VI, and anti-hyperlipidemic constituents from the pericarps of Sapindus rarak. Chem. Pharm. Bull. 2009, 57, 198-203. [CrossRef] [PubMed]

76. Morikawa, T.; Xie, Y.; Asao, Y.; Okamoto, M.; Yamashita, C.; Muraoka, O.; Matsuda, H.; Pongpiriyadacha, Y.; Yuan, D.; Yoshikawa, M. Oleanane-type triterpene oligoglycosides with pancreatic lipase inhibitory activity from the pericarps of Sapindus rarak. Phytochemistry 2009, 70, 1166-1172. [CrossRef] [PubMed]

77. Setijono, S.; Arumingtyas, E.L.; Mastuti, R.; Indriyani, S. Study on Flowering Development Biology of Sapindus rarak DC. Int. J. Agric. For. Plant. 2016, 3, 72-75.

78. Wangchuk, P.; Yeshi, K.; Jamphel, K. Pharmacological, ethnopharmacological, and botanical evaluation of subtropical medicinal plants of Lower Kheng region in Bhutan. Integr. Med. Res. 2017, 6, 372-387. [CrossRef] [PubMed]

79. Sun, C.; Wang, L.; Liu, J.; Zhao, G.; Gao, S.; Xi, B.; Duan, J.; Weng, X.; Jia, L. Genetic structure and biogeographic divergence among Sapindus species: An inter-simple sequence repeat-based study of germplasms in China. Ind. Crops Prod. 2018, 118, 1-10. [CrossRef]

80. Gafur, M.A.; Obata, T.; Kiuchi, F.; Tsuda, Y. Acacia concinna saponins. I. Structures of prosapogenols, concinnosides AF, isolated from the alkaline hydrolysate of the highly polar saponin fraction. Chem. Pharm. Bull. 1997, 45, 620-625. [CrossRef]

81. Tezuka, Y.; Honda, K.; Banskota, A.H.; Thet, M.M.; Kadota, S. Kinmoonosides A-C, three new cytotoxic saponins from the fruits of Acacia concinna, a Medicinal Plant Collected in Myanmar. J. Nat. Prod. 2000, 63, 1658-1664. [CrossRef]

82. Todkar, S.; Chavan, V.; Kulkarni, A. Screening of secondary metabolites and antibacterial activity of Acacia concinna. Res. J. Microbiol. 2010, 5, 974-979. [CrossRef]

83. Chavan, H.V.; Bandgar, B.P. Aqueous extract of Acacia concinna pods: An efficient surfactant type catalyst for synthesis of 3-carboxycoumarins and cinnamic acids via Knoevenagel condensation. ACS Sustain. Chem. Eng. 2013, 1, 929-936. [CrossRef]

84. Boonmee, S.; Kato-Noguchi, H. Allelopathic activity of Acacia concinna pod extracts. Emirates J. Food Agric. 2017, 205-255. [CrossRef]

85. Poomanee, W.; Chaiyana, W.; Intasai, N.; Leelapornpisid, P. Biological activities and characterization of the pod extracts from sompoi (Acacia concinna linn) grown in northern Thailand. Int. J. Pharm. Pharm. Sci. 2015, 7, 237-241.

86. Raju, A.S.; Rao, S.P. Reproductive Ecology of Acacia concinna (Shikakai) and Semecarpus Anacardium (Marking nut), with a note on pollinator conservation in the Eastern Ghats of Visakhapatnam district, Andhra pradesh. In Proceedings of the National Seminar on Conservation of Eastern Ghats, Tirupati, India, 22-24 March 2002.

87. Kiuchi, F.; Gafur, M.A.; Obata, T.; Tachibana, A.; Tsuda, Y. Acacia concinna saponins. II. Structures of monoterpenoid glycosides in the alkaline hydrolysate of the saponin fraction. Chem. Pharm. Bull. 1997, 45, 807-812. [CrossRef]

88. Poomanee, W.; Chaiyana, W.; Randall Wickett, R.; Leelapornpisid, P. Stability and solubility improvement of Sompoi (Acacia concinna Linn.) pod extract by topical microemulsion. Asian J. Pharm. Sci. 2017, 12, 386-393. [CrossRef]

89. Brown, K.S. Diversity, disturbance, and sustainable use of Neotropical forests: Insects as indicators for conservation monitoring. J. Insect Conserv. 1997, 1, 25-42. [CrossRef]

90. Panyaphu, K. Conservation and Sustainable Use of Ethnomedicinal Plants by MIEN PEople in Nan Province. Ph.D Thesis, Chiang Mai University, Chiang Mai, Thailand, January 2012.

91. Scherrer, A.M.; Motti, R.; Weckerle, C.S. Traditional plant use in the areas of Monte Vesole and Ascea, Cilento National Park (Campania, Southern Italy). J. Ethnopharmacol. 2005, 97, 129-143. [CrossRef] [PubMed] 
92. Tangjitman, K. Vulnerability prediction of medicinal plants used by Karen people in Chiang Mai province to climatic change using Species Distribution Model (SDM). Ph.D Thesis, Chiang Mai University, Chiang Mai, Thailand, July 2014.

93. Van On, T.; Quyen, D.; Jones, B.; Wunder, J.; Russell-Smith, J. A survey of medicinal plants in BaVi National Park, Vietnam: Methodology and implications for conservation and sustainable use. Biol. Conserv. 2001, 97, $295-304$. [CrossRef]

94. Junsongduang, A. Roles and importance of sacred forest in biodiversity conservation in Mae Chaem district, Chiang Mai province. Ph.D Thesis, Chiang Mai University, Chiang Mai, Thailand, February 2014.

95. Kebede, M.; Yirdaw, E.; Luukkanen, O.; Lemenih, M. Plant community analysis and effect of environmental factors on the diversity of woody species in the moist Afromontane forest of Wondo Genet, South Central Ethiopia. Biodivers. Res. Conserv. 2013, 29, 63-80. [CrossRef]

96. Kalmykova, Y.; Rosado, L.; Patrício, J. Resource consumption drivers and pathways to reduction: Economy, policy and lifestyle impact on material flows at the national and urban scale. J. Clean. Prod. 2016, 132, 70-80. [CrossRef]

97. Cattarino, L.; Hermoso, V.; Bradford, L.W.; Carwardine, J.; Wilson, K.A.; Kennard, M.J.; Linke, S. Accounting for continuous species' responses to management effort enhances cost-effectiveness of conservation decisions. Biol. Conserv. 2016, 197, 116-123. [CrossRef]

98. Sher, H.; Aldosari, A.; Ali, A.; de Boer, H.J. Economic benefits of high value medicinal plants to Pakistani communities: An analysis of current practice and potential. J. Ethnobiol. Ethnomed. 2014, 10, 71. [CrossRef] [PubMed]

(C) 2019 by the authors. Licensee MDPI, Basel, Switzerland. This article is an open access article distributed under the terms and conditions of the Creative Commons Attribution (CC BY) license (http://creativecommons.org/licenses/by/4.0/). 